\title{
CORRECTION
}

\section{Correction to: Mapping global Al governance: a nascent regime in a fragmented landscape}

\section{Lewin Schmitt ${ }^{1,2}$ (])}

Published online: 20 September 2021

(c) Springer Nature Switzerland AG 2021

\section{Correction to: Al and Ethics}

https://doi.org/10.1007/s43681-021-00083-y

When this article was published, the second affiliation by the author had been forgotten by a typesetting mistake. It should have been:

${ }^{2}$ Institut Barcelona d'Estudis Internacionals (IBEI), Barcelona, Spain

Also, the Author asked to add a funding note:

Funding: The author has received funding from the European Union's Horizon 2020 Research \& Innovation programme under Grant Agreement no. 822654: "Global
Governance and the European Union: Future Trends and Scenarios (GLOBE).

The original article has been corrected.

Publisher's Note Springer Nature remains neutral with regard to jurisdictional claims in published maps and institutional affiliations.

The original article can be found online at https://doi.org/10.1007/ s43681-021-00083-y.

Lewin Schmitt

Lewin.schmitt@upf.edu

1 Department of Political and Social Sciences, Pompeu Fabra University, Barcelona, Spain

2 Institut Barcelona d'Estudis Internacionals (IBEI), Barcelona, Spain 